\title{
Influence of Self-Regulatory Policy of Auditing Profession on Audit Expectation Gap: A Qualitative Methodological Approach
}

Paul N. Onulaka

Department of Accounting, Faculty of Business and Law, Leeds Beckett University Leeds, United Kingdom

Corresponding Author

Martin Samy

Professor, Department of Accounting, Faculty of Business and Law, Leeds Beckett University Leeds, United Kingdom

Doi:10.5901/mjss.2017.v8n1p96

\section{Abstract}

This study examined the influence of self-regulation of auditing profession on audit expectation gap (AEG) in Nigeria with particular reference to respective perceptions of audit partners and pension fund administrators. The motivation for embarking on this exploratory research is born out of many years concern over the speedy erosion of confidence in the auditing profession after the collapse of many blue chip companies in Nigeria to which the external auditors were given 'clean bill of health' shortly before their demise. The theoretical framework adopted for this study was role theory propagated by Porter in her earlier study. This study also adopts the interpretivist or post-positivist epistemological approach. As exploratory study, semi-structured faceto-interview method was used for data collection. After the transcription of the recorded tape, a thematic data analysis method was used to analyse the data. The outcome of the study indicates that self-regulatory policy influenced the auditing standard setting. It was also found that some outdated provisions in the Nigerian company Act on appointment, remuneration and removal of external auditors contributed largely to audit expectation gap in Nigeria. This research responds to the need for a government intervention on auditing standard setting and establishment of transparently independent oversight body for auditing standard setting distinct from the present Financial Reporting Council that adopt auditing standards produced by the Institute of Chartered Accountants of Nigeria.

Keywords: Self-regulation, Qualitative Method, Audit expectation gap, Nigeria.

\section{Introduction}

The present study is aimed at investigating the effect of the self-regulatory policy of auditing profession and its influence on standard setting and audit expectation gap (AEG) in Nigeria with a view to exploring the perceptions of the audit partners and the fund managers on the above research topic.

The motivation for embarking on this exploratory research is born out of many years concern over the speedy erosion of confidence in the auditing profession after the collapse of many blue chip companies in Nigeria of which the external auditors were given 'clean bill of health' shortly before their demise.

Regulation provides a means of achieving defined goals, by adopting rules directed at shaping conduct or controlling behaviour in some way, and then putting machinery in place to enforce those rules (Baldwin, 2004).According to the UK National Consumer Council's Report published in November, 2000, titled "Model of Regulation from Selfregulation to Regulation" it was noted that issues affecting consumers are rooted in the presumption that consumers are the best judges of their own interests both in making decisions, exercising choices and having real influence as buyers and users of goods and services (Bartle \& Vass, 2005). In one of the recent study by (Islam, 2013) in New Zealand it was noted that a profession is subjected to self-regulation, when it has its own rules and regulations that it follows in its daily 
affairs which are not prescribed by the government. Accounting profession is such a type of voluntary self-regulatory profession which has its own professional standards that monitor accountants and audit firms (Public Oversight Board, 2011). Unlike some other professions, accountants and auditors have quite a lot of responsibilities towards the society. According to Swinson (1991p.21) various testimonies pointing to a steady acceleration of negative sentiment towards the auditing profession, have been found in the auditing literatures. Swinson (1991) further noted that the profession will remain in the firing line because it can no longer be allowed to get away with that cosy system of the profession policing itself which is the basis of self-regulation. The study under reference concluded by claiming that complete disregard for accountability and democratization of auditing standards setting has clearly demonstrated that the profession has not operated in the 'public interest' and indeed cannot.

\subsection{The theoretical foundation of the study}

In order to provide a theoretical explanation on the regulatory influence for the existence of an audit expectation gap in Nigeria this study adopted a role theory as propounded by Porter (1990) and modified version of Davidson (1975) Based on role theory an auditor can be viewed as occupying a status or position as a profession in the social system (Lee et al, 2010). Due to the position of a profession, auditors are required to comply with the prescriptions ascribed to them by society. This position or status has been described in auditing literature as a role (Porter and Gowthorpe, 2004). According to Davidson (1975) failure to conform to the ascribed role or to meet role expectations in some cases create the risk of social action to enforce conformity and to penalize deviant behaviour. For duties to be reasonably expected of auditors, they must be compatible with auditors' role in society and cost-beneficial for auditors to perform (Lee et al, 2010). It has been proposed that auditors' role in society is constituted by the attitudes, values and behaviour expected of those who occupy the social position of auditors, by those who have an identifiable relationship with the role position, that is, by role senders. It is further postulated that the social position of auditors is that of members of a recognised profession acting as instruments of social control within the corporate accountability process. Davidson (1975) claimed that the role of the auditor is subject to the interactions of the normative expectations of the various interest groups in society which by and large may be described as different role senders having some direct or indirect relationship to the role position. According to Porter and Gowthorpe (2004) finding, the linchpin in narrowing the gap is perceived to be the duties which are reasonably expected of auditors. It is these duties about which society needs to be educated to eliminate the reasonableness gap, and it is these duties which need to be embodied in auditing standards and performed by practitioners in order to close the performance gap. It is submitted that, if this three-fold approach is adopted, rapid progress will be made towards narrowing the gap and, as a consequence, criticism of auditors will be reduced and the credibility of the profession will be restored. In line with Porter (1990); Oseni and Ehimi (2010) the theory to explain the role of auditors and the auditing regulators has been developed based on three basic elements, namely, the concept of role, the attributes of auditors as professionals, development and discharge of regulatory oversight of audit practice. Davidson provides a helpful diagram to demonstrate the complicated relationship of auditors and regulators in society, and this has been adapted to explain the Nigerian context as depicted in Figure 1.1 below.

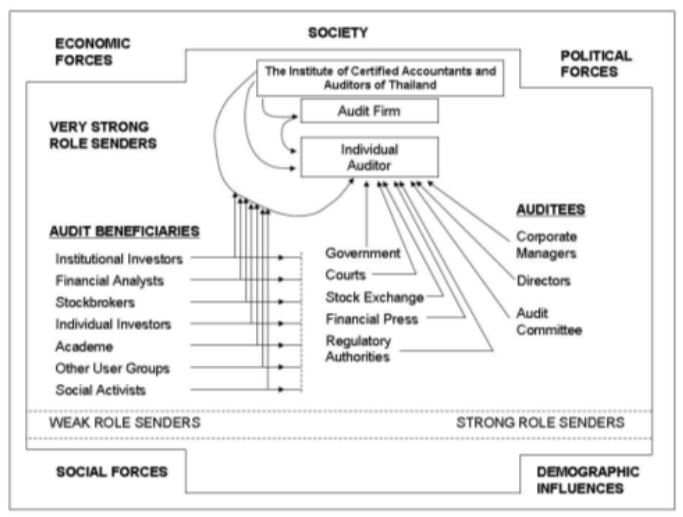

Source: Adapted from Davidson (1975) 
Lee et al (2009) relying on the work of Davidson (1975) emphasizes that groups holding expectations on the auditor's role are also performing their role as required by the expectations of their respective social and professional constituent groups. He further claimed that different groups such as the fund manager, shareholders, members of the public, and regulators of the accountancy profession may hold varying expectations of their auditors, and these expectations may also be likely to change from time to time based on their own role requirements and the interaction of social, economic and political forces in society.

Davidson explains that 'the individual auditor is subject to the role expectations of the organizations of which he is a member' (i.e. the audit firm and professional associations) 'and to the expectations of those for which he is providing direct or indirect services' (e.g. management, shareholders, members of the public, and regulators of the accountancy profession), and therefore finds himself in a 'multi-role, multi-expectation' situation which in turn gives rise to the problems of role conflict. Davidson argues that role conflict exists because there may be conflicting expectations on the role of auditors, as well as internalized subjective conflict, which in turn limits the performance of auditors. Porter (1990) cited by Lee et al (2010) has provided the following examples of different types of role conflict that auditors may encounter to include:

- Inter-role conflict: this is a situation where auditors undertake a management consultancy services to a company's management as well as the company's external auditor. 'These positions may cause conflicting expectations' (Lee et al, 2009 p.5).

- Intra-role conflict: Auditors could be confronted by incompatible expectation from various groups in the society which have a relationship with their position as an auditor. For example, management might expect auditors not to reveal 'confidential information' such as problems in connection with the company's viability in the audit report as it believes it can be damaging to the company's future but the ethical rule on confidentiality from the regulatory body may support the action. However, shareholders might well expect that such information should be disclosed in the audit report. Hence, the auditor is subject to conflicting expectations.

- Subjective role conflict: Auditors may be expected by their audit clients to conduct a quality audit but at the same time they are pressured to minimize time and cost of the audit. In short, given the conflict resulting from the multi-role expectations placed on auditors, it is of no surprise that the role expectations, as perceived by auditors, are different from the expectations held by interest groups in society. The audit expectation gap is the obvious outcome.

In line with Porter (1990 and 1993; Lee et al (2010) the role of the auditors can be viewed in terms of the interactions of the normative expectations of the various role senders in society that have some direct or indirect relationship with the role position, as well as their own perceptions of that role. Lee et al (2010) argued that there could be differences between the expectations of the auditors and of their role senders which in turn give rise to an expectation gap. For the purpose of this study, auditees are the corporate management, the institutional investors represented by fund managers, audit beneficiaries are the capital market operators and shareholders and they have been used as the auditors' role senders including the court, government agencies and the regulatory bodies as can be found in figure 1.1 above. (Porter (1993)

However, users' expectations remained unchanged although the audit profession has experienced a transition from the role of detecting fraud by verifying all transactions and amounts to giving truth and fairness opinion of financial statements. Thus, this suggests the existence of expectation gap towards audit functions between auditors and users of financial statements may remain unabated (Kasim and Hanafi, 2008). Various empirical studies conducted in the US on the nature and structure of the expectation gap aim to elicit the actual as well as the perceived roles and responsibilities of auditors and attempt to uncover the factors contributing to the expectation gap. Most of the studies ascertain the auditors' and the public's view of the roles and responsibilities of auditors through the use of questionnaire surveys and semi-structured interview (Haniffa and Hudaib, 2007).

\section{Research Method}

To achieve the objectives of this study, a qualitative research approach was adopted for the study.

The following criteria were employed in this research:

* Participants were required to be senior members of audit firm within the post qualification experience of 10 to 25 years and Pension Fund Administrator (PFA) in the capacity of Investment Managers or Portfolio Manager, respectively.

* A minimum of 10 participants must come from one of the 3 regions namely North, East and Western parts of Nigeria. 
* Participants were required to be directly or indirectly responsible for sizeable number of audit clients or related function.

* Participants were currently active in the capital market with close link to Fund Custodians and National Pension Commission. All organisations from which participants were drawn for this study were from private sector.

The sample size of thirty interviews (i.e. 15 interviews for auditors and 15 fund manager's group) is considered suitable for this study because the emphasis here is on quality rather than quantity and the objective is not to maximize numbers but to become saturated with information on the topic (Braun and Clarke 2006; Bordens and Abbott, 2014).

\subsection{Thematic Analysis}

The study adopts a thematic analysis and developed a rigorous phenomenological design to reveal the insights to AEG and Self-regulation policy of auditing profession in Nigeria and beyond. The justification for using this data analysis method is not only that it is the most common method of data analysis used in qualitative work (Pope and May, 1999; Ritchie, Spencer and O'Connor, 2004) but because it's inductive in nature and the process involves analyzing transcripts, identifying themes within those data and gathering together examples of those themes from the text (Burnard, et al 2008).

The basic themes for this study were developed to include those shown under Table 1 to 6 below and they were based on the following research questions.

* To what extent do regulation of auditing profession affect audit expectation gap in Nigeria?

* Do self-regulation of the auditing profession in Nigeria influence audit standard settings that is not meeting the expectations of users of financial statements?

Table 1: Regulatory policy: Thematic analysis of participants' responses on interview questions. Responses from Northern Regional Audit Partners and Northern Regional Pension fund Administrators (NRAP \& NRPFAs).

\begin{tabular}{|c|c|c|c|c|}
\hline Sub-theme 1 & 2 & 3 & 4 & 5 \\
\hline Self-regulation & Audit expectation gap & Uniformity of purpose & Quality control & $\begin{array}{l}\text { Influence on audit standard } \\
\text { setting }\end{array}$ \\
\hline $\begin{array}{l}\text { "Yes, ICAN regulates } \\
\text { itself and has a lot of } \\
\text { influence on the } \\
\text { members' activity by } \\
\text { ensuring efficiency, } \\
\text { quality and integrity" } \\
\left.\left(\mathrm{NRAP}_{1}\right)\right)\end{array}$ & $\begin{array}{l}\text { "sets audit standard to } \\
\text { guide all the practicing } \\
\text { accountants on their } \\
\text { relationship with their } \\
\left.\text { clients"(NRAP }{ }_{1}\right)\end{array}$ & --- & $\begin{array}{c}\text { "for quality control and } \\
\text { this control is in line with } \\
\text { the international standard" } \\
\left(\mathrm{NRAP}_{1}\right)\end{array}$ & $\begin{array}{l}\text { "self-regulation influence the } \\
\text { standard setting"(NRAP } 1)\end{array}$ \\
\hline $\begin{array}{l}\text { "From all indication it is } \\
\text { self-regulating and } \\
\text { something instead of } \\
\text { bridging the expectation } \\
\text { gap is widening } \\
\left.\text { it."( } \mathrm{NRAP}_{2}\right)\end{array}$ & $\begin{array}{c}\text { "it influence the auditing } \\
\text { standard setting on audit } \\
\text { objective because it is ICAN } \\
\text { who is the sole regulator of } \\
\text { audit practice in Nigeria" } \\
\left(\mathrm{NRAP}_{2}\right)\end{array}$ & -- & $\begin{array}{l}\text { "self-regulation in terms of } \\
\text { quality control" }\left(\mathrm{NRAP}_{2}\right)\end{array}$ & $\begin{array}{l}\text { "yes ICAN influenced the auditing } \\
\text { standard setting" (NRAP })\end{array}$ \\
\hline $\begin{array}{l}\text { "yes there is self } \\
\text { regulation by. } \\
\text { ICAN"(NRAP })\end{array}$ & $\begin{array}{c}\text { "Well, the regulatory policy } \\
\text { has a lot of influence in } \\
\text { setting of auditing } \\
\text { standards" (NRAP }{ }_{3} \text { ) }\end{array}$ & -- & $\begin{array}{l}\text { "it is forquality control } \\
\text { reasons and } \\
\text { standardization" (NRAP })\end{array}$ & $\begin{array}{l}\text { "it influence the standard setting } \\
\text { as a regulator" (NRAP })\end{array}$ \\
\hline $\begin{array}{l}\text { "from my own } \\
\text { understanding the } \\
\text { self regulation is not } \\
\text { excellent. I have my } \\
\text { reservation because } \\
\text { many companies are } \\
\left.\text { folding up"(NRAP }{ }_{4}\right)\end{array}$ & $\begin{array}{l}\text { "auditing standard setting } \\
\text { not in the interest of the } \\
\text { public we are deceiving the } \\
\text { public by saying is not the } \\
\text { duty of auditor to detect } \\
\text { fraud" (NRAP })\end{array}$ & $\begin{array}{l}\text { "is for uniformity and } \\
\text { comparison of } \\
\text { performance"(NRAP }) \text {. }\end{array}$ & --- & $\begin{array}{l}\text { "yes I agree it has influence on } \\
\text { audit standard setting" (NRAP } 4 \text { ). }\end{array}$ \\
\hline $\begin{array}{l}\text { "yes ICAN regulates } \\
\text { itself and the auditing } \\
\left.\text { standard" ( } \mathrm{NRAP}_{5}\right)\end{array}$ & $\begin{array}{l}\text { "ICAN also set the auditing } \\
\text { standard" (NRAP } 5 \text { ) }\end{array}$ & -- & --- & $\begin{array}{l}\text { "well it influence the activities of } \\
\text { the members through the standard" } \\
\left(\mathrm{NRAP}_{5}\right)\end{array}$ \\
\hline $\begin{array}{l}\text { "ICAN exert a lot of } \\
\text { influence on the } \\
\text { members by way of self- } \\
\text { regulating their } \\
\text { profession" (NRPFA } 1 \text { ) }\end{array}$ & $\begin{array}{l}\text { "it is still the ICAN who sets } \\
\text { accounting standards and } \\
\text { auditing follow that direction" } \\
\text { (NRPFA } 1)\end{array}$ & $\begin{array}{c}\text { "Yes regulation is for } \\
\text { uniformity and } \\
\text { standardization" (NRPFA }{ }_{1} \text { ) }\end{array}$ & $\begin{array}{l}\text { "the standards is also for } \\
\left.\text { quality control" (NRPFA } A_{1}\right)\end{array}$ & $\begin{array}{l}\text { "what the professional body detects } \\
\text { definitely they will } \\
\text { influence...because if you decide } \\
\text { to go contrary that may result to an } \\
\text { infraction and they may be } \\
\text { penalized" (NRPFA }{ }_{1} \text { ) }\end{array}$ \\
\hline $\begin{array}{l}\text { "ICAN as accounting } \\
\text { body regulates itself" } \\
\left(\text { NRPFA }_{2}\right)\end{array}$ & $\begin{array}{l}\text { "the present auditing } \\
\text { standard is produced by } \\
\text { ICAN" (NRPFA }{ }_{2} \text { ) }\end{array}$ & $\begin{array}{c}\text { "it brought about } \\
\text { uniformity"(NRPFA } 2)\end{array}$ & $\begin{array}{c}\text { "is for quality } \\
\text { harmonization of practice" } \\
\text { (NRPFA } 2)\end{array}$ & $\begin{array}{l}\text { "ICAN influence the audit } \\
\text { standard for interest of their } \\
\text { members" (NRPFA } A_{2} \text { ) }\end{array}$ \\
\hline
\end{tabular}




\begin{tabular}{|c|c|c|c|c|}
\hline Sub-theme 1 & 2 & 3 & 4 & 5 \\
\hline Self-regulation & Audit expectation gap & Uniformity of purpose & Quality control & $\begin{array}{c}\text { Influence on audit standard } \\
\text { setting }\end{array}$ \\
\hline--- & $\begin{array}{l}\text { "Yes there is and that is the } \\
\text { essence of even having a } \\
\text { professional body ..... they } \\
\text { have to set up the rules and } \\
\text { regulations to guide their } \\
\text { members." (NRPFA }{ }_{3} \text { ) }\end{array}$ & --- & \begin{tabular}{|c|} 
"the operational bodies \\
setting standards is to \\
unified the quality and \\
conduct that even makes it \\
easier for comparison" \\
(NRPFA ${ }_{3}$ )
\end{tabular} & $\begin{array}{l}\text { "the influence of regulation is to } \\
\text { protect their members" (NRPFA }{ }_{3} \text { ) }\end{array}$ \\
\hline $\begin{array}{l}\text { ": Based on that } \\
\text { explanation yes, there is } \\
\text { self-regulation of } \\
\text { auditing practice in } \\
\text { Nigeria "(NRPFA } 4 \text { ) }\end{array}$ & & --- & 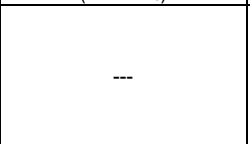 & $\begin{array}{l}\text { "yes since the profession regulates } \\
\text { itself it influence the standard on } \\
\text { the objective of audit" (NRPFA }{ }_{4} \text { ) }\end{array}$ \\
\hline $\begin{array}{l}\text { "Yes, ICAN solely } \\
\text { regulates auditing } \\
\text { standards and their } \\
\text { members in Nigeria" } \\
\text { (NRPFAs) }\end{array}$ & - & $\begin{array}{c}\text { "Well the influence to me is in } \\
\text { the area of quality control, } \\
\text { uniformity and standardization } \\
\text { of practice "(NRPFA })\end{array}$ & -- & $\begin{array}{l}\text { "Yes self-regulatory policy of the } \\
\text { profession will have influence } \\
\text { especially in the area of setting } \\
\text { standard and control of members" } \\
\text { (NRPFA5) }\end{array}$ \\
\hline
\end{tabular}

Table 2: Summary of responses on table 1 for NRAP \& PFAs on Regulatory Policy

\begin{tabular}{|c|l|c|}
\hline S/N & Subthemes & Percentage affirmative responses \\
\hline 1 & Self-regulation & $90 \%$ \\
\hline 2 & Audit expectation gap & $70 \%$ \\
\hline 3 & Uniformity of purpose & $40 \%$ \\
\hline 4 & Quality control & $60 \%$ \\
\hline 5 & Influence on audit standard setting & $100 \%$ \\
\hline
\end{tabular}

From Table 2 above, it should be noted that the main theme from the interview transcript is regulatory policy of the auditing profession. The percentages in each box indicates the number of affirmative responses of the research participants on the various sub-themes .Please see table 1 for more detail. Table 3 below shows the thematic analysis of the Eastern Regional participant responses on the same theme.

Table 3: Regulatory policy: Thematic analysis of participants' responses on interview questions Responses from Eastern Regional Audit Partners (ERAP) and Pension Fund Administrator (ERPFAs)

\begin{tabular}{|c|c|c|c|c|}
\hline Subtheme & 2 & 3 & 4 & 5 \\
\hline Self-regulation & Audit expectation gap & Uniformity of purpose & Quality control & $\begin{array}{l}\text { Influence on audit } \\
\text { standard setting }\end{array}$ \\
\hline $\begin{array}{c}\text { "the self-regulation policy of ICAN } \\
\text { is at par with the international best } \\
\text { practice (ERAP } 1 \text { )" }\end{array}$ & $\begin{array}{l}\text { “ICAN has their own body that } \\
\text { set standard on auditing } \\
\text { and its objective(ERAP } 1)\end{array}$ & $\begin{array}{l}\text { Self-regulation policy framework } \\
\text { is for uniformity and quality } \\
\text { control." }\end{array}$ & $\begin{array}{l}\text { self-regulation policy framework is } \\
\text { for uniformity and quality control." }\end{array}$ & $\begin{array}{l}\text { "ICAN alone sets } \\
\text { audit standard so } \\
\text { they have influence } \\
\text { on it" (ERAP } 1)\end{array}$ \\
\hline $\begin{array}{l}\text { "Institute of Chartered Accountants } \\
\text { of Nigeria is what they regulate us } \\
\text { with" }\left(\mathrm{ERAP}_{2)}\right.\end{array}$ & $\begin{array}{c}\text { "I know the Institute of } \\
\text { Chartered Accountants in } \\
\text { England and Wales (ICIEW) } \\
\text { and ACCA set audit standard } \\
\text { yes doing the same" (ERAP })\end{array}$ & $\begin{array}{l}\text { "try to maintain and ensure that } \\
\text { works are unified and } \\
\text { standardized in line with their } \\
\text { ethical and professional } \\
\text { standards" }\left(\mathrm{ERAP}_{2}\right)\end{array}$ & $\begin{array}{l}\text { try to maintain quality and ensure } \\
\text { that works are standardized } \\
\left(\mathrm{ERAP}_{2}\right)\end{array}$ & $\begin{array}{c}\text { "yes it has } \\
\text { influence in audit } \\
\text { standard setting } \\
\text { standards" (ERAP })\end{array}$ \\
\hline $\begin{array}{l}\text { "Accounting and auditing } \\
\text { profession in Nigeria is well } \\
\left.\text { regulated by ICAN "(ERAP }{ }_{3}\right)\end{array}$ & & $\begin{array}{l}\text { "Self-regulation is to ensure } \\
\text { uniformity" } \\
\left(\mathrm{ERAP}_{3}\right)\end{array}$ & $\begin{array}{l}\text { accounting firms also have their } \\
\text { own ways of quality control } \\
\left(\mathrm{ERAP}_{3}\right)\end{array}$ & --- \\
\hline $\begin{array}{l}\text { "ICAN regulates the practice of } \\
\text { accounting profession in Nigeria } \\
\text { (ERAP } 4 \text { )" }\end{array}$ & $\begin{array}{c}\text { "ICAN sets auditing } \\
\text { standards but formally it was } \\
\text { NASB" (ERAP })\end{array}$ & $\begin{array}{l}\text { to the best of my knowledge it } \\
\text { has brought about uniformity } \\
\text { and standardization in the } \\
\text { practice of the profession" } \\
\left(\mathrm{ERAP}_{4}\right)\end{array}$ & $\begin{array}{c}\text { before you are qualified as a } \\
\text { chartered accountant or combined } \\
\text { with the period of your article-ship, } \\
\text { you must have had } 30 \text { months } \\
\text { practical experience all is to ensure } \\
\text { quality"(ERAP } 4 \text { ). }\end{array}$ & 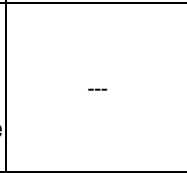 \\
\hline $\begin{array}{l}\text { "Regulation is to guide their } \\
\text { members }\left(E^{-} P_{5}\right)\end{array}$ & & $\begin{array}{c}\text { "the self-regulation policy is for } \\
\text { quality control and } \\
\text { uniformity".(ERAP } 5)\end{array}$ & \begin{tabular}{|c|} 
"the self-regulation policy is for \\
quality control and uniformity". \\
(ERAP 5
\end{tabular} & -- \\
\hline
\end{tabular}




\begin{tabular}{|c|c|c|c|c|}
\hline Subtheme & 2 & 3 & 4 & 5 \\
\hline Self-regulation & Audit expectation gap & Uniformity of purpose & Quality control & $\begin{array}{l}\text { Influence on audit } \\
\text { standard setting }\end{array}$ \\
\hline $\begin{array}{c}\text { "There is self-regulatory policy of } \\
\text { auditing profession in Nigeria" } \\
\left(\text { ERPFA }_{1}\right)\end{array}$ & $\begin{array}{l}\text { "set accounting standards in } \\
\text { line with international best } \\
\text { practice" (ERAP } 1)\end{array}$ & $\begin{array}{l}\text { "it is for uniformity and quality } \\
\text { control reason" (ERPFA } 1) \text {. }\end{array}$ & $\begin{array}{l}\text { "it is for quality control } \\
\left.\text { reason."(ERPFA } A_{1}\right)\end{array}$ & $\begin{array}{l}\text { Yes, self } \\
\text { regulation } \\
\text { influenced setting } \\
\text { of audit standard" } \\
\left.\text { (ERPFA } A_{1}\right)\end{array}$ \\
\hline $\begin{array}{c}\text { "yes, ICAN regulates } \\
\text { Audit practice in Nigeria" (ERPFA } 2 \text { (E) }\end{array}$ & $\begin{array}{l}\text { "the standard setting as well } \\
\text { as regulatory policy is in line } \\
\text { with the international best } \\
\text { practice"(ERPFA } \\
\text { 2) }\end{array}$ & $\begin{array}{l}\text { "the self-regulation by } \\
\text { Accountancy bodies is for } \\
\text { uniformity" (ERPFA }{ }_{2} \text { ) }\end{array}$ & $\begin{array}{c}\text { "for standardization and quality" } \\
\left(\text { ERPFA }_{2}\right)\end{array}$ & $\begin{array}{l}\text { "yes it has a } \\
\text { significant } \\
\text { influence in } \\
\text { auditing practice" } \\
\left(\text { ERPFA }_{2}\right)\end{array}$ \\
\hline $\begin{array}{c}\text { "To a large extent, ICAN regulates } \\
\text { the activities of its members in } \\
\left.\text { Nigeria" (ERPFA }{ }_{3}\right)\end{array}$ & $\begin{array}{c}\text { "ICAN sets auditing } \\
\text { standards for their members } \\
\text { to follow" } \\
\left.\text { (ERPFA }{ }_{3}\right) \\
\end{array}$ & $\begin{array}{l}\text { "It is all of uniformity and } \\
\text { standardization" } \\
\left.\text { (ERPFA } A_{3}\right)\end{array}$ & $\begin{array}{l}\text { "Members continuous professional } \\
\text { education is for quality control " } \\
\left(\text { ERPFA } A_{3}\right)\end{array}$ & $\begin{array}{l}\text { "ICAN influence } \\
\text { auditing practice } \\
\text { in Nigeria" } \\
\left(\text { ERPFA }_{3}\right)\end{array}$ \\
\hline $\begin{array}{l}\text { "Self-regulation gives much room } \\
\text { for the auditors to set auditing } \\
\text { standards and manipulates it to } \\
\text { favor their members especially in } \\
\text { the area of fraud } \\
\left.\text { detection"(ERPFA }{ }_{4}\right)\end{array}$ & $\begin{array}{l}\text { "auditing standards } \\
\text { Are set for both the public } \\
\text { interest and that of the } \\
\text { members" (ERPFA } 4 \text { ) }\end{array}$ & $\begin{array}{l}\text { "Yes, regulation is for } \\
\text { standardization so that } \\
\text { members will not do what they } \\
\text { like that is uniformity" } \\
(\text { ERPFA } 4)\end{array}$ & $\begin{array}{l}\text { regulation is for standardization of } \\
\text { quality and uniformity just like } \\
\text { what obtains from other } \\
\text { professions like medical and legal } \\
\text { profession. }\end{array}$ & $\begin{array}{l}\text { "to me the } \\
\text { selfregulation is a } \\
\text { sort of monopoly } \\
\text { for standard } \\
\text { setting" (ERPFA })\end{array}$ \\
\hline $\begin{array}{l}\text { "the regulatory policy is to protect } \\
\text { their members" } \\
\text { (ERPFA }) .\end{array}$ & $\begin{array}{l}\text { "It is for control reasons that } \\
\text { standard setting has to be } \\
\text { done by ICAN just like what } \\
\text { obtains in UK" (ERPFA })\end{array}$ & $\begin{array}{l}\text { "self-regulation policy though } \\
\text { can help in maintaining } \\
\text { uniformity within the } \\
\left.\text { profession" (ERPFA } A_{5}\right)\end{array}$ & $\begin{array}{c}\text { "Until recently Accountancy bodies } \\
\text { in Nigeria regulates itself and } \\
\text { Auditing Practice in Nigeria mainly } \\
\text { for unification and quality control } \\
\text { reasons" (ERPFA } 5 \text { ) }\end{array}$ & $\begin{array}{c}\text { "yes it can } \\
\text { influence audit } \\
\text { standard setting" } \\
\left(\text { ERPFA }_{5}\right)\end{array}$ \\
\hline
\end{tabular}

Table 4: Summary of responses on table 3 for ERAP \& PFAs on regulatory policy

\begin{tabular}{|c|l|c|}
\hline S/N & Subthemes & Percentage affirmative responses \\
\hline 1 & Self-regulation & $100 \%$ \\
\hline 2 & Audit expectation gap & $80 \%$ \\
\hline 3 & Uniformity of purpose & $100 \%$ \\
\hline 4 & Quality control & $100 \%$ \\
\hline 5 & Influence on audit standard setting & $70 \%$ \\
\hline
\end{tabular}

From table 4 above, it should be noted that the main theme from the interview transcript is regulatory policy of the auditing profession. The percentage in each box indicates the number of affirmative responses of the research participants on the various sub-themes. Please see table 3 for more detail. Table 5 below shows the thematic analysis of the Western Regional participant responses on the same theme.

Table 5: Regulatory policy: Thematic analysis of participants' responses on interview questions Responses from Western Regional Audit Partners (WRAP) and Pension Fund Administrator (WRPFAs) 01-10

\begin{tabular}{|c|c|c|c|c|}
\hline Sub-theme 1 & 2 & 3 & 4 & 5 \\
\hline Self-regulation & $\begin{array}{l}\text { Audit expectation } \\
\text { gap }\end{array}$ & Uniformity of purpose & Quality control & $\begin{array}{l}\text { Influence on audit standard } \\
\text { setting }\end{array}$ \\
\hline $\begin{array}{l}\text { "ICAN regulates } \\
\text { auditing practice in } \\
\text { Nigeria" (WRAP } 1 \text { ) }\end{array}$ & $\begin{array}{c}\text { "ICAN sets auditing } \\
\text { standards on audit } \\
\text { objective in Nigeria" } \\
\left(\mathrm{WRAP}_{1}\right)\end{array}$ & $\begin{array}{c}\text { "it's for uniformity of } \\
\text { practice and } \\
\text { standardization(WRAP } 1 \text { )" }\end{array}$ & $\begin{array}{c}\text { "the people operating the system has } \\
\text { a lot of things to do in making sure } \\
\text { that whatever we do is of the right } \\
\text { quality"(WRAP }) \text {. } \\
\end{array}$ & $\begin{array}{c}\text { "it has no influence at all in AEG" } \\
\left(\text { WRAP }_{1}\right)\end{array}$ \\
\hline $\begin{array}{l}\text { "audit services is } \\
\text { regulated basically by } \\
\text { the Institute"(WRAP })\end{array}$ & $\begin{array}{l}\text { "ICAN set auditing } \\
\text { standards for } \\
\text { members" (WRAP } 2)\end{array}$ & $\begin{array}{l}\text { "auditing standards } \\
\text { promote uniformity in } \\
\text { caring out audit work" } \\
\left(\mathrm{WRAP}_{2}\right)\end{array}$ & $\begin{array}{c}\text { "there are standard that every } \\
\text { accountant and auditors are trained to } \\
\text { adhere to examination and qualifying } \\
\text { stages before you become a } \\
\text { professional accountant the regulation } \\
\text { is to ensure quality" (WRA }{ }_{2} \text { ) }\end{array}$ & $\begin{array}{l}\text { "there is something like self- } \\
\text { regulation, in fact to a large extent } \\
\text { because the Institute of Chartered } \\
\text { Accountants of Nigeria ( ICAN )has a } \\
\text { lot of control and influence over the } \\
\text { activities of members" (WRAP } 2 \text { ) }\end{array}$ \\
\hline $\begin{array}{l}\text { "ICAN regulates } \\
\text { auditing practice in } \\
\left.\text { Nigeria" (WRAP }{ }_{3}\right)\end{array}$ & $\begin{array}{l}\text { "ICAN sets auditing } \\
\left.\text { standard" (WRAP }{ }_{3}\right)\end{array}$ & $\begin{array}{l}\text { "it is for uniformity and } \\
\left.\text { standardization"(WRAP }{ }_{3}\right) \text {. }\end{array}$ & $\begin{array}{l}\text { "ICAN has Code of Ethics to control } \\
\left.\text { its members" (WRAP }{ }_{3}\right)\end{array}$ & $\begin{array}{c}\text { "have influence on the standards } \\
\text { setting agreed because if the bodies } \\
\text { did not the standard setting as I said } \\
\text { before, it will be an all comers affairs } \\
\left(\mathrm{WRAP}_{3}\right)\end{array}$ \\
\hline
\end{tabular}




\begin{tabular}{|c|c|c|c|c|}
\hline Sub-theme 1 & 2 & 3 & 4 & 5 \\
\hline Self-regulation & $\begin{array}{l}\text { Audit expectation } \\
\text { gap }\end{array}$ & Uniformity of purpose & Quality control & $\begin{array}{l}\text { Influence on audit standard } \\
\text { setting }\end{array}$ \\
\hline $\begin{array}{l}\text { "there is self- regulation } \\
\text { of auditing practice in } \\
\text { Nigeria" }\left(\mathrm{WRAP}_{4}\right)\end{array}$ & $\begin{array}{l}\text { "Institute of Chartered } \\
\text { Accountants of } \\
\text { Nigeria (ICAN) is } \\
\text { responsible for } \\
\text { setting audit } \\
\text { standard" (WRAP } 4 \text { ) }\end{array}$ & $\begin{array}{l}\text { "it helps in unifying the } \\
\text { practice of auditing in } \\
\text { Nigeria" (WRAP })\end{array}$ & $\begin{array}{l}\text { "yes I agree it is for standardization } \\
\text { and quality control" }\left(\mathrm{WRAP}_{4}\right)\end{array}$ & $\begin{array}{l}\text { "they have a lot of influence on the } \\
\text { members of their profession". } \\
\text { (WRAP } 4 \text { ) }\end{array}$ \\
\hline $\begin{array}{c}\text { "self-regulation of audit } \\
\text { practice exists in Nigeria } \\
\text { like other parts of } \\
\left.\text { world"(WRAP }{ }_{5}\right)\end{array}$ & $\begin{array}{l}\text { *ICAN set standard } \\
\text { to control the } \\
\text { activities of their } \\
\text { members }\left(\mathrm{WRAP}_{5}\right)\end{array}$ & $\begin{array}{c}\text { *I believe it for things to be } \\
\text { uniform"(WRAP5) }\end{array}$ & $\begin{array}{c}\text { "it's for quality control so that their } \\
\text { product will be comparable with global } \\
\text { standard" (WRAP })\end{array}$ & $\begin{array}{l}\text { "it has influence because they set } \\
\text { the auditing standard themselves" } \\
\text { (WRAP })\end{array}$ \\
\hline $\begin{array}{l}\text { "yes I agree ICAN is the } \\
\text { sole regulator of } \\
\text { auditing practice in } \\
\text { Nigeria"(WRPFA }{ }_{1} \text { ) } \\
\end{array}$ & $\begin{array}{l}\text { "they set standards } \\
\text { for their members to } \\
\text { follow" (WRPFA } A_{1} \text { ) }\end{array}$ & $\begin{array}{l}\text { "I think it make room for } \\
\text { uniformity" (WRPFA } 1 \text { ) }\end{array}$ & $\begin{array}{l}\text { "the regulation also serve as quality } \\
\text { control through MCPE" (WRPFA } 1 \text { ) }\end{array}$ & $\begin{array}{l}\text { "oh yes regulation has influence on } \\
\text { the standard setting" (WRPFA }{ }_{1} \text { ) }\end{array}$ \\
\hline $\begin{array}{l}\text { "ICAN has the } \\
\text { responsibility of } \\
\text { regulating audit practice } \\
\text { in Nigeria"' (WRPFA } 2 \text { )" }\end{array}$ & \begin{tabular}{|c|} 
"I think they have \\
committee that set \\
standards for the \\
members in practice" \\
(WRPFA 2$)$ \\
\end{tabular} & $\begin{array}{c}\text { "it is for public interest } \\
\text { because it make room for } \\
\text { uniformity" (WRPFA }\end{array}$ & $\begin{array}{l}\text { "this regulation is used to ensure } \\
\text { quality service that members are } \\
\text { current through seminars and } \\
\left.\text { workshops" (WRPFA }{ }_{2}\right)\end{array}$ & $\begin{array}{l}\text { "certainly it influenced the standard } \\
\left.\text { setting" (WRPFA }{ }_{2}\right)\end{array}$ \\
\hline $\begin{array}{l}\text { "auditing and accounting } \\
\text { practice is self- } \\
\text { regulated in } \\
\left.\text { Nigeria"(WRPFA }{ }_{3}\right)\end{array}$ & \begin{tabular}{|c|} 
"yes they set \\
auditing standard \\
like other profession" \\
"(WRPFA 3 )
\end{tabular} & \begin{tabular}{|c|} 
"regulation is for \\
uniformity and the interest \\
of the members and also to \\
protect them from liability" \\
"(WRPFA 3 )
\end{tabular} & $\begin{array}{l}\text { "I agree it is control purposes" } \\
\left.\text { "(WRPFA }{ }_{3}\right)\end{array}$ & $\begin{array}{l}\text { "it has influence on the members } \\
\left.\text { activities" "(WRPFA } A_{3}\right)\end{array}$ \\
\hline $\begin{array}{l}\text { "auditing profession } \\
\text { normally regulate } \\
\text { itself'(WRPFA } 4 \text { ) }\end{array}$ & $\begin{array}{l}\text { I think there is new } \\
\text { body made to be } \\
\text { setting standard but } \\
\text { before now it was } \\
\text { ICAN" "(WRPFA } 4 \text { ) }\end{array}$ & $\begin{array}{c}\text { "I agree it is uniformity } \\
\text { and standardization" } \\
\text { "(WRPFA } 4 \text { ) }\end{array}$ & --- & $\begin{array}{l}\text { Definitely it should have influence } \\
\text { especially in telling what audit scope } \\
\text { should be" "(WRPFA }{ }_{4} \text { ) }\end{array}$ \\
\hline $\begin{array}{l}\text { "the Act of parliament } \\
1965 \text { allows ICAN to } \\
\text { regulate audit practice } \\
\text { in Nigeria(WRPFA } 5 \text {. }\end{array}$ & 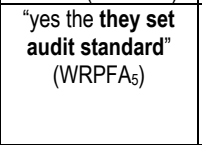 & $\begin{array}{c}\text { "well I believe it is for the } \\
\text { interest of their members } \\
\text { so the they compare notes } \\
\text { that 's } \\
\text { uniformity(WRPFAs) }\end{array}$ & \begin{tabular}{|c|} 
"it is for quality control reason so \\
that they can see a bases to punish \\
an one that did not comply" (WRPFA $A_{5}$ )
\end{tabular} & $\begin{array}{c}\text { "it can influence the standard } \\
\text { setting because members are made } \\
\text { to obey" (WRPFA }\end{array}$ \\
\hline
\end{tabular}

Table 6: Summary of responses on table 5 for WRAP \& PFAs on Thematic analysis on Regulatory policy

\begin{tabular}{|c|l|c|}
\hline S/N & Sub-themes & Percentage affirmative responses \\
\hline 1 & Self-regulation & $100 \%$ \\
\hline 2 & Audit expectation gap & $100 \%$ \\
\hline 3 & Uniformity of purpose & $100 \%$ \\
\hline 4 & Quality control & $90 \%$ \\
\hline 5 & Influence on audit standard setting & $90 \%$ \\
\hline
\end{tabular}

From table 6 above, it should be noted that the main theme from the interview transcript is regulatory policy of the auditing profession. The percentage in each box indicates the number of affirmative responses of the research participants on the various sub-themes. Please see table 5 for more detail.

\section{Discussion of Findings}

\subsection{Self-regulation of Auditing Practice}

All the participants interviewed in each region that is the Eastern, Northern and Western Nigeria agreed that the Institute of Chartered Accountants of Nigeria (ICAN) regulates itself and auditing standard setting in Nigeria. The respondents claim that the regulatory policy is in line with Act No. 15 of 1965 that established the Institute. Most of the participant agreed that there is no independent oversight body that sets auditing standards in Nigeria. They said that recently, a new government agency called the Financial Reporting Council has just been set up to take responsibility of accounting standard setting in Nigeria (see tables 1- 6 above). The finding indicates that average of $96 \%$ of the research participants from the 3 regions agreed that the Institute of Chartered Accountants of Nigeria regulates itself without independent 
oversight. The above finding is in line with Lahey (2012) claimed that to be self-regulating means to be trusted with the authority of the state, i.e. with the authority to administer binding law. According to him, the rationale for this trust is always the idea that the interests of the public are served by self-regulation. Majority of the audit partners said that audit timing and low fee payment contributed much to expectation gap. According to them, it is impossible for auditor to do a thorough job on a financial statement that takes accountants 12 months to prepare within a limited timeframe of 3 weeks. This is a subjective role conflict as outlined in the theoretical framework of this study in section 1.1. Auditors may be expected by their audit clients to conduct a quality audit but at the same time they are pressured to minimize time and cost of the audit. 'In short, given the conflict resulting from the multi-role expectations placed on auditors, it is of no surprise that the role expectations, as perceived by auditors, are different from the expectations held by interest groups in society. The audit expectation gap is the obvious outcome'. (Lee et al, 2010 p.5). The sections that follow offer discussions on the issue of regulation, audit standard setting and expectation gap.

\subsection{Standard setting and expectation gap}

In order to link the theoretical underpinning of this study with the research findings the principles of role theory outlined in Section 1.1 implied that the role of the auditors can be viewed in terms of the interactions of the normative expectations of the various role senders in society that have some direct or indirect relationship with the role position, as well as their own perceptions of that role. The research participants (audit partners and the fund managers) respective perceptions suggested that there could be differences between the expectations of the auditors and of their role senders which in turn give rise to an expectation gap. For the purpose of this study, fund managers and other audit beneficiaries have been used as the auditors' role senders. Porter (1993) and Lee et al, (2010) claimed that to narrow the expectation gap effectively, deficient auditing standard component must be addressed along with the reasonableness gap. From tables 1 to 6 as outlined in section 2 above, it is evident that The Institute of Chartered Accountants of Nigeria (ICAN) sets Auditing Standards and regulates the activities of their members in practice. An average of $90 \%$ of the research participant from all region agreed that selfregulation has significant influence in the setting of auditing standard since the standards are set to guide the members as to the scope and objective of audit with the resultant effect of increasing expectation gap. Although the audit partners agreed that certain provision of the standard on audit objective fall short of public expectations but they claimed that the regulatory policy is in line with what is obtainable in other parts of the world.

The sentiment expressed by these participants is in line with the findings in Salehi (2007) study in Malaysia where it was claimed that one of the findings on the reasons for audit expectation gap is due to the contradiction between minimal government regulation of the accounting profession, and the profession's right to self-regulation, particularly, the problem of the profession's overprotection of self-interest .Similarly, Humphrey et al, (1993) and Lee \&Azham (2008) observed that the self-regulatory monopoly granted to the accounting and auditing profession has been questioned with regard to which extent it operates in the public interest. In addition, a similar study by Olowokere (2011) it was found that the refusal of auditors to assume responsibility for fraud detection and reporting exercise; and their involvement with nonaudit services and self-regulation policy exert a lot of influence to audit expectations gap in Nigeria.

Over $80 \%$ of the respondents said that selfregulation has advantage of unification of practice and quality control. This assertion is in line with the findings in Baldwin (2004) study in US where it was found that regulation provides a means of achieving defined goals, by adopting rules directed at shaping conduct or controlling behaviour in some way, and then putting machinery in place to enforce those rule The assertion on uniformity is also in line with Lee, Ali and Gloeck (2009) study in Malaysia where it was noted that Malaysia Institute of Accountants (MIA) under Section 10(a) of the Accountants Act 1967, MIA has the responsibility to establish rules and regulations for the advancement of the accounting profession and for the prevention of unlawful and dishonourable practices by members of the profession.

\section{Conclusion and Recommendations}

One of the causal factors which have increased audit expectation gap despite previous efforts by accounting profession to reduce the gap is the self-regulatory framework of the profession that empowered the profession to determine what should be the audit objective even though it may run short of public expectations. The policy implications for the study include the need for government and policy makers to revamping some of the existing obsolete legal pronouncements that relate to auditors' responsibilities, appointment and remunerations in our companies law. 


\subsection{Limitations of the study}

This research focuses on audit partners and pension fund administrators. The researcher would have like to collect data from other users of financial statements like banks, brokers and shareholders in general. This could have given a more robust and wider spread of research participant. This is a possible limitation for this study. However, as a phenomenological investigation, the justification for using a limited number of participants from specialized field has been outlined in section 2 above.

\section{References}

Baldwin, R. (2004), "The New Punitive Regulation, Modern Law Review", Vol. 67, No.:3, pp.351-383

Bartle, I. \& Vass P. (2005), "Self-regulation and the Regulatory State: A Survey of Policy and Practice"; Research Report No. 17,. Center for the study of regulated industries,. University of Bath School of Management

Bordens, K.S., Abbott, B.B. (2014) Research Design and Methods: A Process Approach; 9th edition; McGraw-Hill International Edition, New York.

Braun, V and Clarke, V (2006), "Using thematic analysis in psychology", Qualitative research in Psychology, Vol. 3, No. 2. pp. 77-101

Braun and Clarke (2006, 2012), "The method we developed', Successful Analysis of qualitative Data, p.178

Burnard, P. Gill, P. Stewart, K. Treasure, E. \& Chadwick, B, (2008),"Analysing and presenting Qualitative data", British Dental Journal Vol.204, pp. 429-432

Davidson, L.(1975). 'The role and responsibilities of the auditor: perspective, expectations and analysis: A research paper for the commission on auditors' responsibilities. Responsibility Rhetoric", Journal of Business Ethics Spring

Haniffa, R. \&Hudaib, M. (2007), "Locating Audit Expectations gap within a cultural Context: the case of Saudi Arabia", Journal of Accounting, Auditing and Taxation Vol.16, No.2, pp.1-28

Humphrey, C. (2008). Auditing research: A review across the disciplinary Divide, Accounting, Auditing \& Accountability Journal, Vol.21; no.2, pp.170-203.

Humphrey, C., Loft, A., \& Woods, M. (2009), The global audit profession and the international financial architecture: Understanding regulatory relationships at a time of financial crisis. Accounting, Organizations and Society; Vol. 34; no.6/7, pp. 810-825

Islam, M.(2013), "Auditing in the 21st Century: Has Self-regulation Failed?", Journal of Modern Accounting and Auditing, ISSN 15486583 August 2013, Vol. 9, No. 8, 1059-1069 Kasim, M. A., and Hanafi, R.M. (2008), 'Existence of Audit Expectation gap in Malaysia', Malaysian Accounting Review; Vol. 7; no.1, pp. 89-106

Lahey W. (2012) Self-Regulation and Unification Discussions in Canada's accounting Profession; A Framework for Uniting the Canadian Accounting Profession, online: http://cpacanada.ca/a-frameworkfor- uniting-the-Canadian-accounting-profession/.

Lee, T.H., Azham, Md, A. (2008), "Evolution of Auditing: An analysis of the historical Development", Journal of Modern Accounting and Auditing, Vol' 4, No.12. pp.1-6

Lee, T.H., Ali, A. Md., \&Gloeck, J.D. (2009), "The Audit Expectation Gap in Malaysia: An Investigation into its Causes and Remedies" South African Journal of Accontability And Auditing Research, Vol.9: pp. 57-88.

Lee, T.H., Ali, A. Md., Gloeck, J.D., Yap, C.S.,YL, N.G., Boonyanet, W. (2010), 'The Audit Expectation Gap in Thailand', Southern African Journal of Accountability and Auditing Research Vol 10: pp. (1-17)

Olowokere, J.K. (2011), "Stakeholders Perception of Audit Performance Gap in Nigeria", International Journal of Accounting and Finance, Vol.1, No. 1, pp. 152-172.

Oseni, A.I., \& Ehimi, C.O. (2010), "Existence and Nature of Audit Expectation Gap: Nigerian Perspective', .Asian Economic and Financial Review Vol..2; no. 8 pp.1051-1063

Porter, B.(1990). The audit-expectation-performance gap and the role of external auditors in society. Unpublished PhD thesis, Massey University.

Porter, B. (1993), An Empirical Study of the Audit Expectation Performance Gap. Accounting And Business Research, Vol.24 no.93; pp.49-68

Porter, B. \&Gowthorpe, C. (2004), Audit Expectation Performance Gap in the UK In 1999 and Comparison with New Zealand in 1999. The Institute of Chartered Accountant of Scotland Edinburgh

Ritchie, J. Spencer, L. O'Connor, W. (2004,) "Carrying out qualitative analysis, Qualitative Research practice", pp. 219-262, London: Sage Publications

Salehi, M.M., (2007), "Reasonableness of Audit Expectation Gap: Possible Approach to Reducing the Gap", International Journal of Audit Practice, Vol. 3; pp.50-59.

Swinson, C. (1991), "Time to take the bull by the horns", Accountancy, February 1991, pp.275-288. 